This item was submitted to Loughborough's Research Repository by the author.

Items in Figshare are protected by copyright, with all rights reserved, unless otherwise indicated.

\title{
Margaret Cavendish and war
}

PLEASE CITE THE PUBLISHED VERSION

https://www.aup.nl/en/book/9781641891776/a-companion-to-the-cavendishes

\section{PUBLISHER}

Amsterdam University Press / ARC Humanities Press

\section{VERSION}

AM (Accepted Manuscript)

\section{PUBLISHER STATEMENT}

This book chapter was accepted for publication in the book A Companion to the Cavendishes. The definitive published version is available at https://www.aup.nl/en/book/9781641891776/a-companion-to-the-cavendishes.

\section{LICENCE}

CC BY-NC-ND 4.0

\section{REPOSITORY RECORD}

Gill, Catherine. 2020. "Margaret Cavendish and War". Loughborough University. https://hdl.handle.net/2134/11950344.v1. 


\section{Chapter 15. Margaret Cavendish and War}

\section{Catie Gill}

Focussing on Margaret Cavendish's Natures Pictures (1656), this chapter explores how that work serves as a reminder of warfare by acting, as Marina Leslie has noted, as "an emblem of disordered times.". The “emblem" of war most recognised in Cavendish's body of work is the heroic fighter; in particular, the soldier, being a character that crosses generic boundaries, has been the subject of detailed critical assessment. Because some of the most impressive protagonists in the field are female characters who take inspiration from the most positive images that literature and society could offer, Cavendish is believed to celebrate the female warrior. Such an explanation of the way that battlefield ethics operate has never wholly coincided with the critical response to the text that I will be examining, which is also the story from Natures Pictures that Leslie identifies as emblematizing disorder. "Assaulted and Pursued Chastity," despite its superficial resemblance to the femme forte tradition, has always prompted more dystopian, Hobbesian focus on the brutality of war, and reflections on the abuse of women. The real-life historical circumstances that war inflicted, as I will show, left Cavendish probing the negative impact of war, and unrest of the times.

Military history, at least that which was too overtly fascinated with the tactics of battle, did not interest Cavendish; but she was greatly concerned with the ethics of war, and also its effects. While "Assaulted and Pursued Chastity" cannot be said fully to establish the heroism of war, her biography, The Life of the Thrice Noble ... William Cavendish, Duke of

\footnotetext{
${ }^{1}$ Marina Leslie, “Evading Rape and Embracing Empire in Margaret Cavendish's Assaulted and Pursued Chastity," in Menacing Virgins: Representing Virginity in the Middle Ages and Renaissance, ed. Kathleen Kelly-Coyne and Marina Leslie (Newark: University of Delaware Press, 1999), pp. 179-97, pp. 185, 179.
} 
Newcastle (1667), comes much closer to identifying the best in human nature as represented in the figure of the loyal soldier fighting for a noble cause. However, as Deborah Boyle has noted in her analysis of seventeenth-century ethics and politics, "humans vary widely in their natural moral qualities" and "Cavendish evidently does not think that the naturally good and the naturally bad are evenly distributed; the naturally good are in the minority." ${ }^{2}$ Looking at the representation of the field of battle, in the light of Boyle's arguments, Cavendish's attitudes to war will emerge within the constructs of the honour code, from within both a story and a biography.

The Life is to be examined alongside Natures Pictures for the reason that it establishes the principles that Newcastle considers worth fighting for, and so provides an insight into what motivates the man of honour. Contrasting the literary against the non-literary, as critics interested in the depictions of battlefield scenarios in drama have already done, means exposing the permeability of boundaries. Both Vimala C. Pasupathi and Alexandra Bennett, for example, observe areas of overlap between Cavendish's drama and the Life. If, as Pasupathi and Bennett suggest, Cavendish seeks to deploy literary motifs effectively in her biography, what does this say about attempts to influence the reader's perceptions of Newcastle's role in war? ${ }^{3}$ Most blatantly, for example, Cavendish avers "in all actions and

\footnotetext{
${ }^{2}$ Deborah Boyle, "Fame, Virtue, and Government: Margaret Cavendish on Ethics and Politics," Journal of the History of Ideas, 67, no. 2 (April 2006): 251-89 at 260.

${ }^{3}$ Vimala C. Pasupathi, “Old Playwrights, Old Soldiers, New Martial Subjects: The Cavendishes and the Drama of Soldiery," in Cavendish and Shakespeare, Interconnections, ed. Katherine Romack and James Fitzmaurice (Aldershot: Ashgate, 2006), pp. 121-46; Alexandra G. Bennett, "Fantastic Realism: Margaret Cavendish and the Possibilities of Drama," in Authorial Conquests: Essays on Genre in the Writings of Margaret Cavendish,
} 
undertakings where my Lord was in person himself, he was always victorious." ${ }^{4}$ We might apply the insights already mapped in relation to drama to "Assaulted and Pursued Chastity."

Cavendish's reputation as an author is, in part, built on her establishment of herself as a war writer who could comment perceptively on contemporary experiences, as well as on the ideas that shaped history. It is part of her value as a writer that when reflecting on a topic she both self-consciously assesses the limits of genre, and qualifies the effects that language or "sense-impressions" have on the imagination. ${ }^{5}$ It will thus serve the analysis of this chapter to turn, in the final section, to a discussion of Cavendish's reflections on aesthetics, and to the gendering of war. As a result of these intersecting features of Cavendish's work, her place as a war writer can be established in relation to output produced about or in direct response to conflict.

\section{1: "The Sweetness of Peace ... the Misery of War"6}

ed. Line Cottignies and Nancy Weitz (Madison: Fairleigh Dickinson University Press, 2003), pp. 179-193 (esp. 183-84). I follow Pasupathi's method of reading literary against nonliterary text, but my findings do not corroborate her argument that, in Cavendish's literature, Newcastle represents incompetence in war.

${ }^{4}$ Margaret Cavendish, The Life of William Cavendish, ed. C. H. Firth (London, 1886; repr. Kessenger Publishing, n.d), p. 79.

5 “Sense impressions" is Sarasohn's term. Lisa Sarasohn, The Natural Philosophy of Margaret Cavendish (Baltimore MD: Johns Hopkins University Press, 2010), p. 39.

${ }^{6}$ Margaret Cavendish, Sociable Letters, ed. James Fitzmaurice (Plymouth: Broadview, 2004), Letter 185, p. 251. "Those that never had the Sweetness of Peace, or have not known the 
Cavendish wrote Natures Pictures before she turned to composing the Life of Newcastle, and by this point in the Cavendishes' history, all of the experiences that were significant to the Marquess's military reputation already lay behind him. But it is useful to begin with some impressions of war from the Life, rather than the chronologically earlier book, for the details it relates about Newcastle's war record. The portrait in book one of the biography deals in depth with the Marquess's experiences during the first two years of civil war (1642-1644), when he was Commander of the Northern Armies, and ultimately answerable to King Charles I. The significance of the Life is that it offers retrospective, and ameliorative, discussion of Newcastle's career. As a character study, it has its origins in the great lives by Plutarch, and the tragedies of Shakespeare, which adds a profound dimension to this account of the loyal soldier fighting gloriously for the cause. ${ }^{7}$

Cavendish attributes a statement to Newcastle on the dawn of battle that seems to be representative of how he explained his war-time allegiances, "[he thinks] it his duty rather to hazard all, than to neglect the commands of his Sovereign." ${ }^{8}$ Book 1's depiction of battle, indeed, reveals how Cavendish reacts to the outcomes of war as it affected her husband: Newcastle did "hazard all," but lost. She is constrained in her history by her husband's command to avoid writing "to the prejudice or disgrace" of others, which means there is little detail on Newcastle's royalist allies, and by her self-prescribed role: "neither doth it belong to me now to write ... anything else but what concerns the history of my noble Lord." 9 These

Misery of War, cannot be truly and rightly Sensible of either." This statement was made in response to the riot in Antwerp.

${ }^{7}$ See Pasupathi, “Old Playwrights," passim.

${ }^{8}$ Cavendish, Life, p. 19.

${ }^{9}$ Cavendish, Life, p. 106. 
parameters establish the purpose of the biography, which is to stand in solidarity with the Marquess (now Duke).

The Life has the advantage of being able to view events in perspective, and by Cavendish's own confession was written from the relative ease of "a retired country life.". 10 Natures Pictures, meanwhile, engages with the post-civil war society described in one of the stories in the volume as providing "no Joy, nor Comfort," which is to say, it was composed just after the civil wars, when England was a Commonwealth. ${ }^{11}$ In response, Cavendish comments with the urgency of a writer expressing her commitment to the continuing cause of monarchy. The events of this part of Cavendish's life are well known; yet they provide significant insights into the circumstances that she found herself in when writing Natures Pictures, and are crucial context for identifying her imperatives.

Natures Pictures was produced after years of exile, first in France (1644-1647), then in Antwerp, by 1648, via Rotterdam. Cavendish was not wholly cut off from her native home as she returned, in 1651, spending one and a half years, mostly in London, and was accompanied by her brother-in-law Charles Cavendish, in order that both of them might petition for their land rights. ${ }^{12}$ In her autobiography, Cavendish recalls that Newcastle was labelled the "greatest traitor to the State" at that time, showing how heavily suspicion could

${ }^{10}$ Cavendish, "To His Grace, The Duke of Newcastle," in Life, p. xlix.

${ }^{11}$ Margaret Cavendish, “A Description of Civil Wars,” in Natures Pictures (London, 1656), p. 88 .

${ }^{12}$ Anna Battigelli, Margaret Cavendish and the Exiles of the Mind (Kentucky: University of Kentucky Press, 1998), pp. 22, 48; Emma L. E. Rees, Margaret Cavendish: Gender, Genre, Exile (Manchester: Manchester University Press, 2003), pp. 35, 36; Cavendish, Life, pp. 97, 107. 
fall on royalists, particularly if they had been prominent supporters of the King during the wars and likely remained so. ${ }^{13}$ While Cavendish's base when she was writing Natures Pictures was Antwerp, allusions in the text suggest that her thoughts might have been on England. She wrote explicitly, in one story, about her own experiences before the Whitehall committees, and in another story characterised the parliamentarians' exercise of power as "tyranny." ${ }^{14}$ Hence, what she witnessed in the twin locations of England and Antwerp is key to unlocking the ways in which Natures Pictures seeks to infuse the stories and poems with contemporary details. Cavendish was instinctively political in the way she approached war, for reasons that can be traced directly to her circumstances.

Being in England in the early 1650s during the newly established republic would have revealed to her that the royalist cause had not been extinguished. The early 1650 s saw the efforts, ultimately thwarted, of Prince Charles to reclaim the throne in his father's name in the battles of Dunbar and Worcester, the failure putting an end to civil war, until the unrest at end of the decade, and subsequently the Restoration. Royalist writing of the Commonwealth period, whether from England, or (as is true of many of Cavendish's texts) composed in exile, was extremely likely to have a political dimension as a result of how dramatically the country

${ }^{13}$ Cavendish, “A True Relation of my Birth,” in Life, pp. 275-318 (p. 298).

${ }^{14}$ Natures Pictures directly links back to Cavendish's time in England in a story about "Happ'land" which discusses her appearance before the sequestration committee (p. 93). The autobiographical significance is highlighted by Rees, Margaret Cavendish, p. 77. For the account of parliamentary "tyranny," see "A Description of the Civil Wars," Natures Pictures, p. 88 . 
was changing. ${ }^{15}$ Cavendish would have been aware of these events even without the perspective gained from being in England, as Newcastle both offered himself in the service of the Prince in the event of a military rebellion, and (when refused) was in correspondence with key royalist figures with oversight of the plot. ${ }^{16}$

As well as the influence of the sojourn in England, Cavendish must have been affected by experiences in Europe. Though her time abroad was not without its compensations, life in exile was not wholly peaceful. As David Norbrook has observed, during the 1640s in France, where Cavendish was first exiled, "the leaders of the Fronde were ready to make common cause with civic leaders against absolutism, and in taking refuge in Antwerp from the disorders that were besetting Paris, the Cavendishes were reenacting the exile from a turbulent public sphere that had already taken them from England." ${ }^{17}$ That Cavendish found Antwerp relatively comfortable is evident from her correspondence, published as Sociable Letters (1664), and written during her residence. This city's literary and intellectual circles, its art and architecture, may have given her much comfort. ${ }^{18}$

\footnotetext{
${ }^{15}$ Jerome De Groot, Royalist Identities (Basingstoke: Palgrave, 2004); Robert Wilcher, The
} Writing of Royalism, 1628-1660 (Cambridge: Cambridge University Press, 2001).

${ }^{16}$ Katie Whitaker, Mad Madge: Margaret Cavendish, Duchess of Newcastle, Royalist, Writer, and Romantic (London: Chatton and Windus Whitaker, 2002), pp. 129-34;

Cavendish, Sociable Letters, Letter 33, pp. 83-4; Letter 50, p. 100; Letter 196, p. 263. Cavendish, Life, pp. 115, 121, 123.

${ }^{17}$ David Norbrook, "Women, the Republic of Letters, and the Public Sphere in the MidSeventeenth Century," Criticism, 46, no. 2 (Spring 2004): 223-20 at 231.

${ }^{18}$ See James Fitzmaurice's essay in this volume; Ann Hughes and Julie Sanders, "Gender, Geography and Exile: Royalists and the Low Countries in the 1650s," in Royalists and 
However, the Sociable Letters also respond to localised conflict in terms of its unsettling effect on the emigrés, Margaret especially, and show the city was not entirely peaceful. In letters 172 and 185, in particular, the focus on "Mutiny," and the "Diverse, and Different Reports, some that the Army is coming to Destroy the City, and others, that the Souldiers have liberty to Abuse all Women, others, that all the City shall be put to the sword," results in Cavendish acknowledging "Fear is an Absolute Conqueror." ${ }^{19}$ It is not thought that the events were any more than a localised riot, but Cavendish's account suggests that painful memories of conflict made the situation seem worse than in truth it was. The epigraph to this section, "the sweetness of peace ... the misery of war" indeed is taken from a letter written reflecting on the riot.

War, its memory and its ongoing effects, therefore exerted a measurable influence on Cavendish during the period directly before she began to write Natures Pictures. The fractious context she found herself in, particularly in France, but also occasionally in Antwerp, would have reminded her of unrest in her native England. Politically, since she did not accept the authority of the Commonwealth and as her strongest alliances were with the group of royalists who believed in the reinstatement monarchy, she would have experienced the ebbs and flows of contemporary factionalism. Furthermore, it seems that emotionally the memories of civil war probably troubled her. Her writing from the years directly preceding the publication of Natures Pictures gives further indication that the war, and its effects, exert a hold over her imagination. Poems and Fancies (1653) features verse about a "ruined" country that has been devastated by war, and additionally, figures the horror of the regicide

Royalism During the English Civil Wars, ed. Jason McElligott and David L. Smith (Cambridge: Cambridge University Press, 2007), pp. 128-48.

${ }^{19}$ Cavendish, Sociable Letters, Letter 172, p. 237; Letter 185, p. 251. 
using the standard poetic figure for kingship - the hunted stag - hence showing her desire to engage with the recent past. ${ }^{20}$ The Worlds Olio (1655) devotes significant space to assessing political matters, especially competing models of government, and the counterpoint, rebellion and war: poor leadership and popular unrest's negative effect is assessed. ${ }^{21}$ Moreover, sections of Natures Pictures" "The She Anchoret" would ruminate on constitutional questions not dissimilarly. ${ }^{22}$

Some years before Cavendish writes "Assaulted and Pursued Chastity," therefore, war has become a common, almost perennial theme, and as a writer she seemingly tasks herself with excavating both the personal and political changes it brings about. Hero Chalmers points out that Cavendish's Natures Pictures (1656) addresses "scattered Royalist communities," which suggests that one aim of Cavendish in exile is to forge connections with political allies, some of whom would be in England, and some on the continent, like her. ${ }^{23}$ How Natures Pictures produces a sense of an ongoing dialogue with her readership around the war and its effects becomes clear through "Assaulted and Pursued Chastity." Her writing deploys some of the same methods that can be found in Poems and Fancies and The Worlds Olio, such as indirect or allusive political comment, as in royalist tropes that relate to the regicide, but are extraneous to this chapter's analysis of the text's military themes. Moreover, there are

\footnotetext{
${ }^{20}$ Margaret Cavendish, Poems and Fancies (London, 1653), "The Ruine of the Island" and "The Hunting of the Stag," pp. 118-20, 113-16.

${ }^{21}$ Margaret Cavendish, The Worlds Olio (London, 1655). See in particular the third book.

${ }^{22}$ Cavendish, “The She Anchoret,” Natures Pictures, pp. 287-357 (especially pp. 326-30).

${ }^{23}$ Hero Chalmers, Royalist Women Writers 1650-1689 (Oxford: Clarendon Press, 2004), p.
} 130. See also Chalmers' essay in this volume, and her discussion of the femme forte tradition in Royalist Women. 
occasions when the characters sit in council to debate issues, and strategies, which echo the discussions of state matters in her previous texts. ${ }^{24}$ "Assaulted and Pursued Chastity" goes further than the previous war writing because it is the first extended prose narrative written by Cavendish that follows a soldier.

In the story, the chief protagonist, Travellia, who is cross-dressed and therefore consistently taken for a man, forges an alliance with the Queen of Amity, whom she champions after learning of the threat that her country faces from the King of neighbouring Amour. ${ }^{25}$ Driven by a desire to marry the Queen that is so strong he presses for advantage even after she has refused his suit, the King behaves like the ubiquitous villain from romance. Inspired by Travellia, the Queen leads the attack, because her lieutenant knows that with the sovereign on the field, the soldiers will fight valiantly: "in each heart such loyal love may grow ... honour [will] close your days." ${ }^{26}$ Travellia is an especially good rhetorician, and her speeches tend to be effective in achieving the desired result. The presence of royal characters in this story speaks to the evocation of real-world themes, such as the idea that Royalists fight more bravely when their monarch is willing to take to the field with them.

The lessons of the war do not stop there, however, as Cavendish also wants to depict the sovereign-favourite relationship in ways that chime with other concerns, not least, how to

\footnotetext{
${ }^{24}$ Margaret Cavendish, "Assaulted and Pursued Chastity," in The Blazing World and Other Writings, ed. Kate Lilley (London: Penguin, 1992), pp. 45-118 (pp. 71, 91). Travellia escapes execution. Last-minute reprieve from a death sentence inverts King Charles I's experience, and functions as a royalist trope.

${ }^{25}$ The heroine is referred to using three names: Miseria, Affectionata, and Travellia. I use the name most frequently applied.

${ }^{26}$ Cavendish, “Assaulted and Pursued Chastity,” p. 92.
} 
gain the support of the rank and file. Certainly, as Lois Potter accurately observes, the depiction of power in Cavendish shows a clearer insight than her contemporaries' into the relationship between heroism and fantasy. ${ }^{27}$ The next phase of Amity's military strategy demonstrates Potter's point because, as the battle progresses, more and more idealised versions of sovereignty are articulated. This occurs as the soldiers "with one voice ... make vows that they would never forsake their Queen," after a rousing speech that inspires them to take back their captured sovereign. Travellia expresses their choice: "[either] redeem your country's loss, or sacrifice your lives in services thereunto," and they rise to the challenge. ${ }^{28}$ The way Travellia provokes the soldiers' loyalty validates royalism through expressing antipathy towards the capturing of a monarch, here fictional, but evocatively potent within the historical frame.

While this discourse of mutuality between sovereign and subject, army leader and troops, agrees with the romance's tone, and purpose, it to a degree also chimes with realworld events. Cavendish's Life depicts the same basic set of relations that the political theorist Thomas Hobbes was defining in the period - after all, though "Assaulted and Pursued Chastity" is generically a romance, it is also an allegory of contemporary relations. The story seems to conceive of a social contract that secures the obedience of the subject to the sovereign through recognition of the benefits that they are believed to gain from the

${ }^{27}$ Lois Potter, "The Plays and Playwrights: 1642-60," in The Revels History of Drama in English, ed. Phillip Edwards, Gerald Eades Bentley, Kathleen MacLuskie, Lois Potter, vol. 4 (London: Methuen, 1981), pp. 261-77, p. 279.

${ }^{28}$ Cavendish, “Assaulted and Pursued Chastity,” p. 95. 
arrangement, or "contract." ${ }^{29}$ This language of affective relations has already been identified in "Assaulted and Pursued Chastity," which conceives of the love between sovereign and subject as mutually beneficial, and which assumes that it is in the interest of the subject to give up their life for the Queen.

A very similar tone is struck in the Life. Newcastle commits himself to the command of the King on the eve of the battle of Marston Moor with this vow: "he was ready and willing, for his part, to obey his Highness in all things." Despite the order to engage the enemy having been delivered by Charles I's second in command, Prince Rupert, Newcastle says the letter with the King's instruction should be obeyed "[as] if his Majesty was there in person." ${ }^{30}$ Newcastle, in other words, acknowledges his subordination to the King, but conceives of the feelings he bears to him as love - for his person, and his office. This is the origin of the social contract according to Hobbes. Meanwhile, after a speech from Newcastle on the battlefield, his troops, the White Coats, offered obedience to his command "being as glad of my Lord's proffer, as my Lord was of their readiness, [and] went on with the greatest courage." 31 This, too, expresses the solders' understanding of their place in the social hierarchy, and their contract with the monarch, via his ensign, the Marquess. It is also clear from the echoes between "Assaulted and Pursued Chastity," and this battle-section of the Life, that Cavendish was thinking about Hobbesian obligation across a number of texts.

\footnotetext{
${ }^{29}$ Victoria Kahn, “'The Duty to Love': Passion and Obligation in Early Modern Political Theory," Representations, 68, no. 9 (Autumn 1999): 84-107; Kahn, "Margaret Cavendish and the Romance of Contract," Renaissance Quarterly, 50, no. 2 (Summer 1997): 526-66.

${ }^{30}$ Cavendish, Life, p. 76.
${ }^{31}$ Cavendish, Life, p. 78.
} 
The eventual success of Travellia's army by the end of the "Assaulted and Pursued Chastity" reinforces the affective relations that have been so important to the story. Not only is the Queen saved, but Travellia (no longer cross-dressed), receives her troops' approval: "Heaven bless you, of whatever sex soever you be." 32 "Assaulted and Pursued Chastity" shows through the exceptional leadership of the femme forte, Travellia, and the exemplary relationship between sovereign and subject, the fabulous victory that can be accomplished when the conditions are right. By contrast, as is well known, Newcastle's day on the field ended disastrously, because the men in Prince Rupert's army were routed, and Newcastle's own troops "were killed in rank and file." ${ }^{33}$ Historians account Marston Moor one of the most significant royalist losses in the whole course of the war, and the death of Newcastle's White Coats was, as Cavendish said, akin to annihilation. ${ }^{34}$ By way of a side note, the only the troops who made any headway against the Parliamentarians that day were those under the command of Cavendish's brother, Charles Lucas (and his co-commander, Lord Goring).

Seen not in terms of the success or failure of military conduct, but as a measure of the soldier and leader's worth, some additional conclusions can be drawn from Cavendish's depiction of battle. Both "Assaulted and Pursued Chastity" and the Life depict Cavendish's engagement with the values that a soldier upholds on the battlefield. The protagonists' actions during battle, the reasons why they fight, and the way that they interact with other soldiers, are significant markers of their worth. External factors (such as the justness of the cause to which the individual commits themselves, or even their success) may be less valid as a way

\footnotetext{
${ }^{32}$ Cavendish, "Assaulted and Pursued Chastity," p. 114.

${ }^{33}$ Cavendish, Life, p. 79.

${ }^{34}$ Malcolm Wanklyn, Decisive Battles of the English Civil Wars: Myth and Reality

(Barnsley: Penn \& Sword, 2006), pp. 107-34, p. 134.
} 
of assessing a person's honour than other more oblique markers. As Deborah Boyle has observed, internal factors, such as motivation, may be the period's most reliable guide as to individual merit within the honour code. An "almost Kantian" paradox pertains, because the individual who strives to embody the qualities associated with honour has missed the point; honour comes from nature and cannot be counterfeited. ${ }^{35}$ Seeking reward, or consciously behaving in ways to attract plaudits, compromises the individual's worth within the honour code while acting whether or not it brings any benefit to yourself may be the definition of true heroism.

Even Cavendish's Travellia is of questionable merit, judged through this lens: she motivates her troops by declaring "Noble friends, brave soldiers ... we fight for fame." 36 Alternatively, when Cavendish in her autobiography comments on how her father, Thomas Lucas, "did not esteem titles, unless they were gained by heroic actions," she is gesturing towards the same sort of definition of true honour that Boyle has delineated as an ideal, but essentially impracticable standard of merit. ${ }^{37}$ It is therefore apparent that underpinning Cavendish's construction of events at Marston Moor is an idealised version of honour, one that finds value in the apparently selfless sacrifice exhibited that day, in July 1644. She is

\footnotetext{
${ }^{35}$ Boyle, "Fame, Virtue, and Government," p. 268. Boyle indicates that Cavendish revises concepts of honour to include rather than exclude people who actively seek to be remembered, turning fame into a correlative of virtue.

${ }^{36}$ Cavendish, "Assaulted and Pursued Chastity," p. 97.

${ }^{37}$ Cavendish, "A True Relation,” in The Life, p. 275.
} 
bound by standards of veracity in the construction of the account. ${ }^{38}$ And yet, she clearly exercises narrative power, in terms of the text's sensibilities, and tone.

Considerable overlaps between Natures Pictures' literary engagement with war and the biography exist. However, the position of the Life in relation to its subject matter is particularly interesting as the Duke's war record, and reputation, is at stake. As Cavendish remarks in her discussion of the genre of biography, the text is not the full account of events. She has, already in the preface, foregrounded the instruction to omit from the discussion material to the "prejudice or disgrace" of others. ${ }^{39}$ She elaborates, beginning by showing her contentment at working within these parameters, yet ending in a completely different spirit: "I will neither endeavour to make show of eloquence, making speeches that were never spoken ... much less will I write to amuse my readers, in a mystical or allegorical style." Then, at the heart of the matter as she sees it, occurs a piece of doublespeak. She concedes that she will not write of the "disloyal actions" of the "treacherous cowardice, envy and malice of some persons," because she has sworn not to. ${ }^{40}$ In effect, she cannot help but let the reader know that she would say more, if only she could.

Exposing the degree to which Cavendish breaks her promise would be possible through an excavation of inferences in the Life, but is not the work of this chapter. ${ }^{41}$ Instead,

\footnotetext{
${ }^{38}$ See the statement from Newcastle's secretary, John Rolleston, who advised Cavendish. Cavendish, Life, pp. lxv-lxviii.

${ }^{39}$ Cavendish, "The Preface," in Life, lvii.

${ }^{40}$ Cavendish, "The Preface," in Life, lvii.

${ }^{41}$ This would expose how Cavendish allows errors to be attributed to Rupert, Charles I, or the royalists. For how Newcastle repairs his affairs, see Elspeth Graham, “"An After-Game of Reputation': Systems of Representation, William Cavendish and the Battle of Marston
} 
if we accept that the frustration Cavendish expresses in relation to biography is to a degree genuine, then analysis must centre on her more favoured mode - romance. Cavendish does not just depict the charismatic femme forte figure defending the innocent sovereign of Amity, she, as Nancy Weitz has noted, constructs an "ideological rift ... slipping ambiguously in and out of moral categories." ${ }^{42}$ Cavendish's romance hence interrogates the other sovereignsubject relations in order to reveal, far more negatively, the exploitative bond between the King and his soldier, and the indolence of rulers. In masculinity's excess, moreover, possessiveness, and sexual violence are the order of the day. In other words, Cavendish is able to explore "envy and malice" more fully in romance, than in biography.

Readers who enjoy romance narratives are mocked in the Sociable Letters for the high regard in which they hold "feign'd Heroes," and Cavendish further criticises romance in Natures Pictures for being over-blown, "ridiculous to reason." ${ }^{43}$ Romance's frivolous plotlines make it easy to overlook the sophistication that some writers bring to the genre. ${ }^{44}$ Romance in fact offers a powerful corrective to human failing through the analysis of vice, as Paul Salzman has considered, by demonstrating how it deploys a polemical mode that both

Moor," in Authority, Authorship and Aristocratic Identity in Seventeenth-Century England, ed. Peter Edwards and Elspeth Graham (Leiden: Brill, 2016), pp. 83-110.

${ }^{42}$ Nancy Weitz, “Romantic Fiction, Moral Anxiety and Social Contract in Cavendish's 'Assaulted and Pursued Chastity,"' in Authorial Conquests, ed. Cottegnies and Weitz, pp. 145-60, p. 150.

${ }^{43}$ Cavendish, Sociable Letters, Letter 21, p. 68; Cavendish, “Assaulted and Pursued Chastity," p. 54.

${ }^{44}$ Helen Hackett, Women and Romance Fiction in the Early Renaissance (Cambridge: Cambridge University Press, 2000). 
works within moral parameters, and complicates them. ${ }^{45}$ Natures Pictures, therefore, utilises the more complex framework that Salzman has identified by bringing rival armies into conflict, which allows for discussion of the contrasting ideals they stand for. Cavendish's Life seemed aggrieved at the instruction that it should point no blame at the real-life enemies of Newcastle. Her romance, however, has greater success in exposing corruption and human frailty. I will have further cause to link the Life to Natures Pictures, having first analysed romance's polemicism.

\section{"Dividing of the Spoils" 46}

In "Assaulted and Pursued Chastity," war is generated by passion; in particular, it arises from the King of Amour's desire for the Queen of Amity. In a different context within Natures Pictures, Cavendish conveys fighting chivalrously as "a game of Honour." 47 This essentially medieval framework, courtly love, is not invalidated in Cavendish's work, but it is certainly reprised, such as through the queering that results from having a woman (cross-dressed) defending the Queen when she has been taken as the prize of battle. ${ }^{48}$ Still further complexity is added through Natures Pictures' rape plot. In a sick society in which fear replaces love, sex and coercion are intimately interlinked. As Amelia Zurcher explains, readers are expected to respond to this genre's ethical conundrums with "the complexity and rigour not consistent

${ }^{45}$ Paul Salzman, English Prose Fiction 1558-1700: A Critical History (Oxford: Clarendon Press, 1985).

${ }^{46}$ Cavendish, "Assaulted and Pursued Chastity,” p. 90.

${ }^{47}$ Cavendish, “A Description of Natural Affection,” in Natures Pictures, pp. 60-63, p. 62.

${ }^{48}$ In "A Description of Natural Affection," the chivalric code is more subtly contradicted. The prince wins the woman, but her marriage is mainly pragmatic. 
with romance's reputation as a wishful or escapist genre." ${ }^{49}$ Cavendish goes some way towards confirming this expectation of the form's sophistication, as in the preface to Natures Pictures she explains its purpose: "[to] admonish ... to direct ... to the best of mankind." 50 While Cavendish does write a number of simple and morally rather traditional stories, her aim is typically higher, such as "Assaulted and Pursued Chastity"'s charting a complex link between masculinity and excess.

In The Blazing World (1666), a character whose military victory looks like the "day of judgement" shows war as the ultimate coercion, through the annihilation of enemies. ${ }^{51}$ The Blazing World scenario confirms that Cavendish's imperative is to look at war's cost, but brief focus on one decision made by the leader, the Empress, shows how morally compromised leadership becomes during conflict. Cavendish's Empress acts to suppress a rebellion, to "reduce by force" the insurgents, which she does at considerable cost through use of superior weaponry, a "flaming fire" targeting their homes. ${ }^{52}$ As Oddvar Holmesland summarises, the Empress's problems with rebellion "[comment] on the intolerable situation

\section{${ }^{49}$ Amelia Zurcher, "The Political Ideologies of Revolutionary Prose Romance," in The Oxford Handbook of Literature and the English Revolution, ed. Laura Lunger Knoppers} (Oxford: Oxford University Press, 2012), pp. 551-66.

${ }^{50}$ Cavendish, "Preface," Natures Picture (London, 1671), sig. B3 ${ }^{\mathrm{r}}$. In addition to the comments on romance discussed here, see also Margaret Cavendish, The Convent of Pleasure and Other Plays, ed. Anne Shaver (Baltimore MD: Johns Hopkins University Press), p. 265; Cavendish, “The Three Wooers,” in Natures Pictures (1656), p. 117-20 (p. 118). ${ }^{51}$ Margaret Cavendish, The Blazing World, in Political Writings, ed. Susan James (Cambridge: Cambridge University Press, 2003), 1-109 (p. 94).

${ }^{52}$ Cavendish, Blazing World, in Political Writings, p. 99. 
in England ... after the civil war," and, hence, dramatize whether authoritarian solutions are ever valid. ${ }^{53}$ The event is likely to divide opinion, which is precisely the aim of this text.

The differences and similarities between Cavendish's Empress and the King of Amour are immediately evident when returning to explore the romance, "Assaulted and Pursued Chastity." This text examines arbitrary government through charting the impact on the state of a ruler who shirks his responsibilities. The King of Amour is uninterested in state affairs to a degree the Empress would not condone, and he is so love-sick that he neglects all other duty. It is probable that Cavendish was alert to romance's anti-monarchical potential, leading her to exercise a degree of caution when discussing royalty, such as her balancing out the picture to include the idealised queen alongside this degenerate king. ${ }^{54}$ However, she is prepared to utilise the romance fascination with taking the indolent ruler to task, through anticourt motifs. ${ }^{55}$ She identifies the King of Amour's weakness as more than his lack of duty and sensual excess, therefore, by turning the focus to his taste in favourites. She for instance notes that the prince "insinuated" himself into the king's favour, and "[having] got such affections in his court living ... he became very powerful," which is a statement implying the

${ }^{53}$ Oddvar Holmesland, "Margaret Cavendish's The Blazing World: Natural Art and the Body Politic," Studies in Philology 96, no. 4 (Autumn 1999): 457-79 at 473.

${ }^{54}$ Rees points out that a writer deploying anti-court satire might want to disassociate herself from the romance genre to deflect attention from content that might cause offence to royalty. See Rees, Margaret Cavendish, p. 112.

${ }^{55}$ See, for example, Basilius in Sir Philip Sidney, The Countess of Pembroke's Arcadia, ed. Maurice Evans (London: Penguin, 1977). 
monarch's judgement is faulty, and which establishes very clearly an anti-court satirical vein to this section of the text. ${ }^{56}$

The king is not only represented as whimsical when in love and uninterested in the realities of government: he is also incapable of inspiring the heroism or devotion which is crucial in war. As a figure designed to represent the indolent ruler character-type, the King of Amour seems to wield arbitrary power. The authority he commands exceeds his inherent qualities as a ruler; he is obeyed because of his position not his judgement. An example of how he treats his subjects badly is the contract that the prince is asked to make once he is a soldier for Amour. The king explains: "Your Faith I'll trust and Courages will try / Then let us see how bravely you dare die." ${ }^{57}$ The king's "try ... how ... you ... die" is surely intended to provoke an uneasy reaction; this is not a leader in whom the subject can place their trust. The social contract is usually built at least on the pretence that there is love between the subject and their monarch; but here, the king rules by fear, which is a symptom of arbitrary government's political arrangements. ${ }^{58}$

The Empress of the Blazing World and the King of Amour are depicted through their actions, their words, but also evidently through the perspective the narrators offer. It is possible for readers to see that the leaders of Amour and the Blazing World are flawed individuals who abuse their power, because the narrator's judgements seep into the text. ${ }^{59}$ Another feature of the narrative sophistication is the near resemblance of some of the characters to well-known people. "Assaulted and Pursued Chastity" might be paralleling the

\footnotetext{
${ }^{56}$ Cavendish, “Assaulted and Pursued Chastity,” p. 89.

${ }^{57}$ Cavendish, “Assaulted and Pursued Chastity,” p. 88.

${ }^{58}$ See Rachel Willey's essay on Machiavellianism in this volume.

${ }^{59}$ For the narrative sophistication of Cavendish, see Brandie R. Siegfried in this volume.
} 
following: Travellia, the femme forte, parallels Queen Henrietta Maria; the King of Amour, an indolent ruler, has some qualities of the young Prince Charles; the rapacious prince equates to the ruthless and daring Prince Rupert. There is an element of risk to this allusive technique that Annabel Patterson identifies in Censorship and Interpretation. Patterson traces why some writers do not, or cannot, push their critique of the powerful home, to censorship, and explains that writers using the allegorical technique may be "unheard or misrepresented." ${ }^{60}$ Cavendish seems to have the confidence to walk the fine line of allegorical romance, which shows how politicised the genre was in her hands.

The story's turning from critiquing leaders to admonishing followers, in this case the armies of Amour, gives further evidence of Cavendish exposing wartime's corruption of values. She also begins to reveal a theme, that "women and children suffer the most when the battles are over." ${ }^{61}$ The soldiers of Amour have internalised their leaders' ruthlessness such that the chivalric code is almost absent from Amour's ranks, as they give themselves over to unrestrained behaviour and indulge their desire to exert power over the vanquished. In the course of battle between Amity and Amour, the Prince, who is in command, is aggrieved that the soldiers fall to "dividing of the spoils" when they should still be fighting. ${ }^{62}$ Readers of Cavendish's text would know how widely practised looting was during the civil wars, so this detail is a pertinent critique. ${ }^{63}$ This focus on plunder is not the only sort of problem

${ }^{60}$ Annabel Patterson, Censorship and Interpretation: The Conditions of Writing and Reading in Early Modern England (Madison: University of Wisconsin Press, 1984), p. 48.

${ }^{61}$ Fitzmaurice, "Introduction," in Sociable Letters, p. 17.

${ }^{62}$ Cavendish, “Assaulted and Pursued Chastity,” p. 90.

${ }^{63}$ Cavendish's family home was twice looted, and bodies in the family tomb disinterred.

Cavendish, True Relation, in Life, pp. 290-92. 
Cavendish describes. The prince sees the opportunity to press his advantage when the Queen of Amity is defenceless. Seizing the queen, whom he sees immediately as "a gift" for the king, the prince takes special care with his prize: "had the spoils been less, he had sent them with some messengers; but being so rich, he durst trust none to guard it but himself." 64

With intricate precision, Cavendish has deployed the word "spoils" twice of the same battle. She would know "spoils" to be a correlative for abuse; by linking the larceny of the soldiers to the capture of the Queen, she is troubling the idea that woman is a possession by using her culture's association of rape with theft. ${ }^{65}$ Cavendish is asking for attention to be paid to war when the conquest is not of territory, but of a woman. Such attitudes are therefore corrosive to the aspects of honour that Cavendish's text most endorses, though Travellia, and therefore "Assaulted and Pursued Chastity," insists on linking rape to war.

Indeed, it is not just "Assaulted and Pursued Chastity" that exposes war's damaging effect on women, their vulnerability to abuse and their treatment as objects to be exchanged. The disintegration of knightly values is neither the first, nor the only, consequence of war; but it is paramount to Cavendish's concerns as a writer who cannot endure to see women's value reckoned in terms of their sexual availability. Lady Orphant, in the play Loves Adventures, has an idealistic view of soldiers, and, when she follows her beau to the wars, she believes he will treat her well: "he will neither use me uncivily, nor cruelly." Lady Orphant is proved right and her chastity is threatened neither by the soldiers nor by her beloved; but her

\footnotetext{
${ }^{64}$ Cavendish, "Assaulted and Pursued Chastity," p. 93.

${ }^{65}$ OED "rape," n., 3.1. Amy Greenstadt, Rape and the Rise of the Author: Gendering
} Invention in Early Modern England (Farnham: Ashgate, 2009). At the end of the story, moreover, Cavendish destabilises the harmony of the ending by referring to soldiers returning to the marriage ceremony with "all the spoils they got in war" (p. 117). 
foster father's warning that women are likely to be used "too civilly" speaks of some dangerous consequences during wartime. ${ }^{66}$ More explicitly, in Cavendish's play Bell in Campo, the men want to send the women far away from battle, knowing the enemy will take them as "slaves, using or abusing them" if they are defeated. ${ }^{67}$ The sexual abuse of women is one of the markers of wartime barbarity that forms a basis of male protectionism, and shame. Women's vulnerability in war results both from the assumption that they are property, and from the power that soldiers hold in determining their fate.

The captured woman is not restricted to Cavendish's literary writing, however. The Life of Newcastle also narrates a war-time story of a woman in peril, and subject to the will of soldiers, once taken in battle. In 1643, royalist troops captured Lady Anne Fairfax, wife to the parliamentary commander Thomas Fairfax. Of the encounter, Cavendish observes:

The enemy that were in the town, it seems, were so discomfited ... they escaped ... some of my Lord's soldiers ... brought [Lady Anne] to his quarters, where she was treated and attended with all civility and respect, and within a few days sent to York in my Lord's own coach. ${ }^{68}$

Cavendish therefore places the emphasis on how Lady Fairfax was treated well, indeed chivalrously, by the Marquess.

However, more might be at stake in this encounter than first appears. Cavendish invokes rape as a persistent threat to women in her literary work; and having established women's vulnerability in war early in her writing career she makes it, indeed, a repeated

\footnotetext{
${ }^{66}$ Cavendish, Loves Adventures, 4.18, in The Convent of Pleasure, p. 51.

${ }^{67}$ Cavendish, Bell in Campo, 2.7, in The Convent of Pleasure, p. 117.

${ }^{68}$ Cavendish, Life, p. 49.
} 
concern. ${ }^{69}$ The cavalier stereotype (or, "rake"), rather than the rapist, is probably what is in Cavendish's mind as she strives to protect her image of Newcastle as an idealised soldier who embodies the best of the chivalric honour code. Cavendish therefore writes as though to head off any insinuations, fully alert to the implication that might be drawn from the detail that the enemy's wife was delivered to Newcastle's "quarters," so she ensures the reader knows that the prisoner was treated with "civility and respect."

The records go further, as can be traced in Parliamentarian documents dealing with the seizure of Lady Fairfax. ${ }^{70}$ It would seem implicit that the frequency with which Cavendish depicts soldiers abusing women taken in war in her literary corpus explains Cavendish's sensitivity to the Fairfax incident when writing the Life; but this case occurred when she was still in England, so there may be other possibilities. Fairfax's return, in fact, occurred after parliament issued the extraordinary resolution that: "order shall be taken for seizing and making Prisoners of all the Ladies, Wives, any Lords, or others that are in actual War against the Parliament," if Lady Fairfax was not promptly returned. Indeed, parliament

69 "Margaret Cavendish must be recognised as the first woman dramatist to represent - and condemn - sexual violence against women.” Marianne Wynne-Davies, “Fornication in my Owne Defence': Rape, Theft and Assault Discourses in Margaret Cavendish's The Sociable Companions," in Expanding the Canon of Early Modern Women's Writing, ed. Paul Salzman (Cambridge: Cambridge Scholars Publishing, 2010), pp. 34-48, p. 46.

${ }^{70}$ Andrew Hopper, “Black Tom”: Sir Thomas Fairfax and the English Revolution (Manchester: Manchester University Press 2007), pp. 192-93. 
went so far as to say it had had compiled a list of women who would be taken in revenge. ${ }^{71}$ Cavendish may or may not have known of these events: Newcastle was not in her orbit, in 1643 , so would she remember this detail in the late1660s, when writing the Life? Surely, the incident is memorable enough, but we cannot be sure as to whether the historical record filters into the text. What is clear, is the anxiety that presents itself in the scene describing Lady Fairfax's visit to the Marquess's “quarters." Since Cavendish is prone to believing the worst soldiers' behaviour culminates in sexual abuse of women, it seems very likely that she knows the subtext of which she writes.

Cavendish's two major works, "Assaulted and Pursued Chastity" and the Life of Newcastle, provide insight into why war writing is so prevalent in her corpus. In the Life's explanation of the writer's purpose, Cavendish signals her intention to tell what she knows: "most of the persons that held any considerable place in the armies, was well known to me," and thus it "[is not] inconsistent with my being a woman, to write of wars." 72 To this evidence of her perception of the importance of personal insight in shaping the Life, some additional reasons can be inferred. Since romance is associatively gendered (though admittedly, more often written for women than by them), she would not find the writing of romance "inconsistent" as a mode through which to express her concern about war, any more than biography. Indeed, romance conceivably has the greatest potential for considering the co-existence of great heroism and great violence; certainly, she takes the exploration of the latter further in her romance than in the Life. Today, we would call the account in "Assaulted

\footnotetext{
${ }^{71}$ Journal of the House of Commons, vol. 3, 27 July, 1643, p. 183. "The Committee for Examinations do take a care to present a List of all the Ladies whose Husbands have been, or are, in actual War against the Parliament.” Cited in part in Hopper, “Black Tom, ” p. 193. ${ }^{72}$ Cavendish, "The Preface," in Life, p. lvi.
} 
and Pursued Chastity" an expose of toxic masculinity and sexual abuse, and would see that not as "inconsistent" but all too commonly a feature of women's writing about war. "In the Ruines of War we suffer Equally with Men," she asserts in the Sociable Letters. ${ }^{73}$

Cavendish conceives of the complexity of the times in which she lives; when writing Natures Pictures, she is instinctively political in the way she interprets the romance tropes, and this has a bearing on how she produces a conclusion. This is evident through Travellia at the end of "Assaulted and Pursued Chastity," because she is still ready for the call to war, even after peace has been declared: "I have laid aside my masculine spirit [i.e. her soldier's role] ... but I shall take it up again, if it be to serve the Queen." 74 Travellia therefore continues to be royalism's political mascot, as she embodies Queen Henrietta Maria's femme forte spirit; if she were to return to the field, it would be for the glory of her country. Travellia is not just a resonant political symbol, however. Cavendish also needs her to be ready to defend herself should that need arise in marriage, hence the importance of her remaining a soldier even at the conclusion. Travellia has always been the most perceptive character in "Assaulted and Pursued Chastity;" and if her instinct suggests the probability of war again breaking out, it is human nature - witness her husband's conflation of love with war - that makes it so. The images in allegorical romance, as ever, have both a political and a personal corollary, exposing human failing and flawed political systems simultaneously.

The impact of war on Cavendish seems less simple to define. Confiding how she “never saw an Army together, nor any Incounters," Cavendish explains how, despite this seemingly lack of exposure to battle, she sees in her mind's eye "Armies ... rais'd in my braine, fought in my fancy, and registerd in my closet." For Cavendish, as has been seen

\footnotetext{
${ }^{73}$ Cavendish, Sociable Letters, Letter 88, p. 140.

${ }^{74}$ Cavendish, “Assaulted and Pursued Chastity,” p. 115.
} 
when she reacts fearfully to disturbances in Antwerp, such a memory triggers alarming "sense impressions": "I am as fearefull as a Hare: for I shall start at the noyse of a Potgun, and shut my eyes at the sight of a bloudy Sword." ${ }^{75}$ Given how evocatively and emotively conflict is represented in her work, it is highly appropriate that she confesses how many emotions are condensed into the imaginative work of writing war.

${ }^{75}$ Cavendish, Poems and Fancies, p. 167; The Natural Philosophy, p. 39. 


\section{Bibliography}

Battigelli, Anna. Margaret Cavendish and the Exiles of the Mind. Kentucky: University of Kentucky Press, 1998.

Bennett, Alexandra G. "Fantastic Realism: Margaret Cavendish and the Possibilities of Drama.” In Authorial Conquests: Essays on Genre in the Writings of Margaret Cavendish, edited by Line Cottignies and Nancy Weitz, pp. 179-93. Madison: Fairleigh Dickinson University Press, 2003.

Boyle, Deborah. "Fame, Virtue, and Government: Margaret Cavendish on Ethics and Politics." Journal of the History of Ideas 67, no. 2 (April 2006): 251-89.

Cavendish, Margaret. The Blazing World and Other Writings. Edited by Kate Lilley. London: Penguin, 1992.

---. The Convent of Pleasure and Other Plays. Edited by Anne Shaver. Baltimore: Johns Hopkins University Press, 1999.

---. The Life of William Cavendish. Edited by C. H. Firth. London, 1886; repr. Kessenger Publishing n.d..

---. Natures Picture. London, 1671.

---. Natures Pictures. London, 1656.

---. Poems and Fancies. London, 1653.

---. Sociable Letters. Edited by James Fitzmaurice. Plymouth: Broadview, 2004.

---. The Worlds Olio. London, 1655.

Chalmers, Hero. Royalist Women Writers 1650-1689. Oxford: Clarendon Press, 2004. 
Graham, Elspeth. ““An After-Game of Reputation': Systems of Representation, William Cavendish and the Battle of Marston Moor." In Authority, Authorship and Aristocratic Identity in Seventeenth-Century England, edited by Peter Edwards and Elspeth Graham, pp. 83-110. Leiden: Brill, 2016.

De Groot, Jerome. Royalist Identities. Basingstoke: Palgrave, 2004.

Greenstadt, Amy. Rape and the Rise of the Author: Gendering Invention in Early Modern England. Farnham: Ashgate, 2009.

Hackett, Helen. Women and Romance Fiction in the Early Renaissance. Cambridge: Cambridge University Press, 2000.

Holmesland, Oddvar. “Margaret Cavendish's The Blazing World: Natural Art and the Body Politic.” Studies in Philology 96, no. 4 (Autumn 1999): 457-79.

Hopper, Andrew. "Black Tom”: Sir Thomas Fairfax and the English Revolution. Manchester: Manchester University Press 2007.

Hughes, Ann and Julie Sanders. "Gender, Geography and Exile: Royalists and the Low Countries in the 1650s." In Royalists and Royalism during the English Civil Wars, edited by Jason McElligott and David L. Smith, pp. 128-48. Cambridge: Cambridge University Press, 2007.

Leslie, Marina. "Evading Rape and Embracing Empire in Margaret Cavendish’s ‘Assaulted and Pursued Chastity."' In Menacing Virgins: Representing Virginity in the Middle Ages and Renaissance, edited by Kathleen Kelly- Coyne and Marina Leslie, pp. 17997. Newark: University of Delaware Press, 1999.

Norbrook, David. "Women, the Republic of Letters, and the Public Sphere in the MidSeventeenth Century." Criticism, 46, no. 2 (Spring 2004): 223-40. 
Pasupathi, Vimala C. “Old Playwrights, Old Soldiers, New Martial Subjects: The Cavendishes and the Drama of Soldiery." In Cavendish and Shakespeare, Interconnections, edited by Katherine Romack and James Fitzmaurice, pp. 121-46. Aldershot: Ashgate, 2006.

Patterson, Annabel. Censorship and Interpretation: The Conditions of Writing and Reading in Early Modern England. Madison: University of Wisconsin Press, 1984.

Potter, Lois. "The Plays and Playwrights: 1642-60." In The Revels History of Drama in English, vol. 4, edited by Phillip Edwards et al., pp. 261-77. London: Methuen, 1981.

Rees, Emma L. E. Margaret Cavendish: Gender, Genre, Exile. Manchester: Manchester University Press, 2003.

Salzman, Paul. English Prose Fiction 1558-1700: A Critical History. Oxford: Clarendon Press, 1985.

Sarasohn, Lisa. The Natural Philosophy of Margaret Cavendish. Baltimore: Johns Hopkins University Press, 2010.

Wanklyn, Malcolm. Decisive Battles of the English Civil Wars: Myth and Reality. Barnsley: Penn \& Sword, 2006.

Whitaker, Katie. Mad Madge: Margaret Cavendish, Duchess of Newcastle, Royalist, Writer, and Romantic. London: Chatton and Windus Whitaker, 2002.

Weitz, Nancy. "Romantic Fiction, Moral Anxiety and Social Contract in Cavendish's ‘Assaulted and Pursued Chastity."” In Authorial Conquests, edited by Line Cottegnies and Nancy Weitz, pp. 145-60. Madison WI: Fairleigh Dickinson, 2003. 
Wilcher, Robert. The Writing of Royalism, 1628-1660. Cambridge: Cambridge University Press, 2001.

Wynne-Davies, Marianne. “Fornication in my Owne Defence': Rape, Theft and Assault Discourses in Margaret Cavendish's The Sociable Companions." In Expanding the Canon of Early Modern Women's Writing, edited by Paul Salzman, pp. 34-48.

Cambridge: Cambridge Scholars Publishing, 2010.

Zurcher, Amelia. “The Political Ideologies of Revolutionary Prose Romance.” In The Oxford Handbook of Literature and the English Revolution, edited by Laura Lunger Knoppers, pp. 551-66. Oxford: Oxford University Press, 2012. 